\title{
RECHTSREGEL
}

Jurnal Ilmu Hukum Vol 1, No 2 Desember 2018

P-ISSN 2622-6235, E-ISSN 2622-6243,

rjih_fh@unpam.ac.id

\section{KEABSAHAN PERJANJIAN JUAL BELI SECARA TIDAK TERTULIS BERDASARKAN HUKUM PERDATA}

\author{
Aan Handriani \\ Fakultas Hukum Universitas Pamulang \\ E-mail: aanhandriani@gmail.com
}

\begin{abstract}
ABSTRAK
Perjanjian jual beli adalah suatu perjanjian timbal balik dimana pihak yang satu (penjual) berjanji akan menyerahkan suatu barang dan pihak lain (pembeli) akan membayar harga yang telah dijanjikan. syarat sahnya sebuah perjanjian adalah Kesepakatan para pihak dalam perjanjian, Kecakapan para pihak dalam perjanjian, Suatu hal tertentu, Suatu sebab yang halal. Jual beli merupakan bentuk transaksi umum yang sering dilakukan oleh masyarakat. Biasanya, perjanjian jual beli dilakukan secara lisan atau tertulis atas dasar kesepakatan para pihak (penjual dan pembeli). "Berdasarkan ketentuan mengenai syarat sahnya suatu perjanjian tersebut, tidak ada satupun syarat dalam Pasal $1320 \mathrm{KUH}$ Perdata yang mengharuskan suatu perjanjian dibuat secara tertulis". Dengan kata lain, suatu Perjanjian yang dibuat secara tidak tertulis juga mengikat secara hukum bagi para pihak yang membuatnya.
\end{abstract}

Kata kunci: Perjanjian, Jual Beli, Kesepakatan Para Pihak. 


\title{
RECHTSREGEL
}

Jurnal Ilmu Hukum Vol 1, No 2 Desember 2018

P-ISSN 2622-6235, E-ISSN 2622-6243,

rjih_fh@unpam.ac.id

\begin{abstract}
$A$ sale and purchase agreement is a reciprocal agreement whereby one party (the seller) promises to deliver a good and the other party (the buyer) will pay the promised price. the terms of the validity of a treaty are the Agreement of the parties to the treaty, the parties' professions in the agreement, a certain matter, a lawful cause. Buying and selling is a common form of transaction that is often done by the public. Typically, the sale and purchase agreement is oral or written on the basis of agreement of the parties (seller and buyer). Under the terms of the terms of the validity of the agreement, there is no requirement in Article 1320 of the Civil Code which requires that an agreement be made in writing. In other words, an Agreement made in an unwritten manner is also legally binding for the parties who make it.
\end{abstract}

Keywords: Agreement, Sale and Purchase, Agreement of the Parties 


\section{PENDAHULUAN}

Proses transaksi jual beli merupakan sesuatu hal yang sering kita jumpai dalam kehidupan sehari-hari, hal tersebut dimaksud karena adanya kesepakatan untuk memperoleh hak diantara kedua belah pihak untuk mendapatkan keuntungan masing-masing. "Pasal 1313 BW memberikan rumusan tentang kontrak atau perjanjian adalah suatu perbuatan dengan mana satu orang atau lebih mengikatkan dirinya terhadap satu orang lain atau lebih".

"Subekti memberikan definisi Perjanjian adalah suatu peristiwa dimana seorang berjanji pada seorang lain atau dimana dua orang itu saling berjanji untuk melaksanakan sesuatu hal. Sedangkan KRMT Tirtodiningrat memberikan definisi perjanjian adalah suatu perbuatan hukum berdasarkan kata sepakat di antara dua orang atau lebih untuk menimbulkan akibat-akibat hukum yang dapat dipaksakan oleh undang-undang." 1

Menurut Salim HS, Perjanjian adalah "hubungan hukum antara subjek yang satu dengan subjek yang lain dalam bidang harta kekayaan, dimana subjek hukum yang satu berhak atas prestasi dan begitu juga subjek hukum yang lain berkewajiban untuk melaksanakan prestasinya sesuai dengan yang telah disepakatinya." ${ }^{2}$

Jual beli merupakan bentuk transaksi umum yang sering dilakukan oleh masyarakat. Biasanya, perjanjian jual beli dilakukan secara lisan atau tertulis atas dasar kesepakatan para pihak (penjual dan pembeli).

Sedangkan barang yang menjadi obyek perjanjian jual beli adalah "haruslah barang yang berada dalam lalu lintas perdagangan sebagaimana diatur dalam pasal 1332 KUHPerdata. Berdasarkan BW

\footnotetext{
${ }^{1}$ Agus Yudha Hernoko, 2010, Hukum Perjanjian Asas Proporsionalitas dalam Kontrak Komersil, PT. Kharisma Putra Utama, Jakarta, hal. 14.

${ }^{2}$ Salim HS, 2008, Hukum Kontrak, Teori \& Tekriik Penyusunan Kontrak, Sinar Grafika, Jakarta, hal. 27.
} 
barang, yang menjadi obyek perjanjian dapat diklasifikasikan menjadi barang yang sudah ada dan barang yang akan ada (relative dan absolut).”

"Perkataan jual beli menunjukan bahwa dari suatu pihak perbuatan dinamakan menjual, sedangkan dari pihak yang lain dinamakan membeli. Istilah yang mencakup dua perbuatan yang bertimbal balik itu adalah sesuai dengan istilah belanda 'Koop en Verkoop" yang juga mengandung pengertin bahwa pihak yang satu verkoopt (menjual) sedang yang lainya koopt (membeli). Dalam bahasa inggris jual beli disebut dengan hanya sela saja yang berarti penjualan (hanya diliat dari sudutnya si penjual). Begitu pula dalam bahasa francis disebut hanya dengan vente yang juga berarti penjualan. Sedangkan dalam bahasa Jerman dipakainya perkataan 'kauf' yang berarti pembelian."3

Sedangkan perjanjian "Jual Beli adalah suatu perjanjian timal balik dimana pihak yang satu (penjual) berjanji akan menyerahkan suatu barang dan pihak yang lain (pembeli) akan membayar harga yang telah dijanjikan (pasal 1457 KUHper)."

Saat terjadinya jual beli

"Jual beli dianggap telah terjadi antara kedua belah pihak seketika setelah kedua belah pihak mencapai kata sepakat tentang barang dan harganya meskipun barang itu belum diserahkan maupun harganya belum dibayar (pasal 1458 KUHPer)". Hal ini sesuai asas konsensualisme dalam perjanjian.

Jual beli yang batal

"Jual beli barang orang lain adalah batal dan dapat memberikan dasar untuk penggantinya biaya kerugian dan bunga jika si pembeli tidak mengetahui bahwa barang itu kepunyaan orang lain (pasal 1471 KUHPer). Jika pada saat penjualan, barang yang

\footnotetext{
${ }^{3}$ Subekti, 1995, Aneka perjanjian, PT. Citra Aditya Bakti, Bandung, hal. 2.
} 
dijual sama sekali musnah. Maka pembelian adalah batal". Tetapi apabila musnahnya hanya sebagian saja maka pembeli dapat memilih antara pembatalan atau pembelian sisa barang (pasal 1472 KUHPer).

"Resiko dalam Jual Beli

Mengenai resiko dalam jual beli ini dalam KUHPer diatur sebagai berikut :

1. Jika kebendaan yang dijual itu berupa suatu barang yang sudah ditentukan, maka barang itu saat pembelian adalah atas tanggungan si pembeli, meskipun penyerahanya belum dilakukan dan si penjual berhak menuntut harganya (Pasal 1460 KUHPer)

2. Jika barang-barang itu dijual menurut berat, jumlah atau ukuran, maka barang-barang itu tetap atas tanggungan si penjual hingga barang-barang tersebut ditimbang, dihitung atau diukur (Pasal 1461 KUHPer).

3. Jika barang yang dijual menurut tumpukan, maka barangbarang itu adalah atas tanggungan si pembeli, meskipun belum ditimbang dihitung atau diukur (Pasal 1462 KUHPer).

4. Biaya akta jual beli dan lain-lain biaya tambahan dipikul oleh si pembeli, jika tidak telah diperjanjikan sebaliknya (Pasal 1466 KUHPer)."4

"Di dalam rumusan Pasal 1313 KUHPerdata mendefinisikan bahwa perjanjian adalah perbuatan dengan mana satu orang atau lebih mengikatkan dirinya terhadap satu orang atau lebih. Perjanjian dengan demikian mengikat para pihak secara hukum, untuk mendapatkan hak atau melaksanakan kewajiban yang ditentukan di dalam perjanjian itu."5 "Di dalam asas kebebasan berkontrak yang

\footnotetext{
${ }^{4}$ Simanjuntak, 2007, Pokok-Pokok Hukum Perdata Indonesia, Djambatan, Jakarta, hal. 356.

${ }^{5}$ I Ketut Artadi dan I Dewa Nyoman Rai Asamara Putra, Op.Cit. hal. 28. ${ }^{5}$ I Ketut Artadi dan I Dewa Nyoman Rai Asamara Putra, Op.Cit. hal. 47.
} 
dijelaskan melalui rumusan Pasal 1338 KUHPerdata menyebutkan bahwa semua perjanjian yang dibuat secara sah, berlaku sebagi Undang-Undang bagi mereka yang membuatnya dan di dalam ayat (3) disebutkan persetujuan-persetujuan harus dilaksanakan dengan etikad baik. Pengertian ini berkaitan dengan asas pacta sunt servanda yang artinya bahwa perjanjian tersebut harus dilaksanakan." "Di dalam rumusan Pasal 1320 KUHPerdata dijelaskan mengenai syarat sahnya perjanjian, yaitu : a). sepakat mereka yang mengikatkan diri, b). kecakapan untuk membuat perjanjian, c). suatu hal tertentu, d). suatu sebab yang halal. Dalam pengertian sepakat pada salah satu unsur Pasal 1320 KUHPerdata adalah syarat amat penting dalam sahnya suatu perjanjian. Sepakat ditandai oleh penawaran dan penerimaan dengan cara : a). tertulis; b). lisan; c). diam-diam; d). simbol-simbol tertentu. Oleh sebab itu, jelas bahwa perjanjian lisan/Tidak Tertulis merupakan perjanjian yang sah karena memenuhi unsur kata sepakat yang terdapat di dalam rumusan Pasal 1320 KUHPerdata. Sehingga para pihak yang mengadakan perjanjian lisan diwajibkan melaksanakan prestasi dari apa yang telah disepakati, seperti yang terdapat di dalam rumusan Pasal 1234 KUHPerdata yang menyebutkan "tiap-tiap perikatan adalah untuk memberikan sesuatu, berbuat sesuatu, dan tidak berbuat sesuatu."6 Apabila ada salah satu pihak yang tidak memenuhi prestasi tersebut, ia telah melakukan wan prestasi.

\section{PERMASALAHAN}

Adapun permasalahan yang diangkat dalam penelitian ini adalah:

1. Bagaimana Keabsahan Perjanjian Jual Beli Secara Tidak Tertulis?

${ }^{6}$ I Ketut Artadi dan I Dewa Nyoman Rai Asamara Putra, Op.Cit. hal. 34. 
2. Bagaimana Hukum Perdata Mengatur Tentang Perjanjian Jual Beli ?

\section{TUJUAN DAN MANFAAT PENELITIAN}

\section{Tujuan Penelitian}

Penelitian ini bertujuan :

a. Untuk mengetahui bagaimana perjanjian jual beli secara tidak tertulis.

b. Untuk mengetahui bagaimana hukum perdata mengatur tentang perjanjian jual beli.

\section{Manfaat Penelitian}

Berdasarkan permasalahan yang menjadi focus kajian penelitian ini dan tujuan yang ingin dicapai maka, diharapkan penelitian ini dapat memberikan manfaat sebagai berikut:

a. Manfaat Teoritis

Penelitian ini diharapkan mampu memberikan sumbangan pemikiran terkait perjanjian, khususnya dalam perjanjian jual beli, serta lebih jauh diharapkan akan menambah pengetahuan hukum bagi penulis serta dapat bermanfaat bagi pembaca.

b. Manfaat Praktisi

Penelitian ini diharapkan juga mampu memberikan sumbangan pemikiran atau bahan pertimbangan dalam merumuskan perjanjian guna meminimalisir persoalannya, serta memberikan kontribusi kepada praktisi hukum.

\section{METODE PENELITIAN}

"Metode pendekatan Jenis metode penelitian yang digunakan dalam penelitian ini, adalah jenis penelitian Yuridis normatif, dalam 
penelitian Yuridis normatif ini Hukum dikonsepkan sebagai apa yang tertulis dalam Peraturan Perundang-Undangan (law in books). Sebagai sumber datanya adalah data sekunder, yang terdiri dari bahan Hukum primer, bahan Hukum sekunder atau data tersier."7 Penulisan karya ilmiah ini melihat pengaturan Hukum yang berhubungan dengan hukum perjanjian Jual Beli Secara Tidak Tertulis (Lisan), apakah aturan tersebut secara tegas mengatur menganai perjanjian, sehingga tersedianya payung hukum yang jelas dan tegas apabila terjadi suatu permasalahan.

Data dianalisis secara kualitatif normatif, meneliti dengan jalan menafsirkan dan membangun pernyataan yang terdapat dalam dokumen per-undang-undangan dan teori berdasarkan Referensi para ahli. Metode analisis kualitatif, berdasarkan data sekunder yang berupa teori, makna dan substansinya dari berbagai literatur, peraturan perundang-undangan, kemudian dianalisis dengan normatifnya undang-undang, teori dan pendapat pakar yang berkaitan, sehingga didapat kesimpulan tentang Keabsahan Perjanjian Jual Beli Secara Tidak Tertulis Berdasarkan Hukum Perdata.

\section{PEMBAHASAN}

\section{Keabsahan Perjanjian Jual Beli Secara Tidak Tertulis}

"Perjanjian merupakan sumber terpenting dalam suatu perikatan. Menurut Subekti, Perikatan adalah "suatu perhubungan hukum antara dua orang atau dua pihak, berdasarkan mana pihak yang satu berhak menuntut sesuatu hal dari pihak yang lain, dan pihak yang lain berkewajiban untuk memenuhi tuntutan itu"."

\footnotetext{
7 Amiruddin Dan Zainal Asikin, 2004, Pengantar Metode Penelitian Hukum, PT RajaGrafindo Persada, Jakarta, hal. 118.

${ }^{8}$ Subekti, 2005, Hukum Perjanjian, Intermasa, Jakarta, hal. 1.
} 
Perikatan dapat pula lahir dari sumber-sumber lain yang tercakup dengan nama undang-undang. Jadi, ada perikatan yang lahir dari "perjanjian" dan ada perikatan yang lahir dari "undang-undang". "Perikatan yang lahir dari undang-undang dapat dibagi lagi ke dalam perikatan yang lahir karena undang-undang saja (Pasal 1352 KUHPerdata) dan perikatan yang lahir dari undang-undang karena suatu perbuatan orang. Sementara itu, perikatan yang lahir dari undang-undang karena suatu perbuatan orang dapat lagi dibagi kedalam suatu perikatan yang lahir dari suatu perbuatan yang diperoleh dan yang lahir dari suatu perbuatan yang berlawanan dengan Hukum (Pasal 1353 KUH Perdata)."

"Di dalam suatu perjanjian pada umumnya memuat beberapa unsur yaitu:

1. Pihak-pihak, paling sedikit ada dua orang. Para pihak yang bertindak sebagai subyek perjanjian, dapat terdiri dari orang atau badan hukum. Dalam hal yang menjadi pihak adalah orang, harus telah dewasa dan cakap untuk melakukan hubungan hukum. Jika yang membuat perjanjian adalah suatu badan hukum, maka badan hukum tersebut harus memenuhi syaratsyarat badan hukum yang antara lain adanya harta kekayaan yang terpisah, mempunyai tujuan tertentu, mempunyai kepentingan sendiri, ada organisasi

2. Persetujuan antara para pihak, sebelum membuat suatu perjanjian atau dalam membuat suatu perjanjian, para pihak memiliki kebebasan untuk mengadakan tawar-menawar diantara mereka

3. Adanya tujuan yang akan dicapai, baik yang dilakukan sendiri maupun oleh pihak lain, selaku subjek dalam perjanjian tersebut. Dalam mencapai tujuannya, para pihak terikat dengan 
ketentuan bahwa tujuan tersebut tidak boleh bertentangan dengan undang-undang, kesusilaan dan ketertiban umum

4. Ada prestasi yang harus dilaksanakan, para pihak dalam suatu perjanjian mempunyai hak dan kewajiban tertentu, yang satu dengan yang lainnya saling berlawanan. Apabila pihak yang satu berkewajiban untuk memenuhi prestasi, bagi pihak lain hal tersebut merupakan hak, dan sebaliknya

5. Ada bentuk tertentu, suatu perjanjian dapat dibuat secara lisan maupun tertulis. Dalam hal suatu perjanjian yang dibuat secara tertulis, dibuat sesuai dengan ketentuan yang ada

6. Syarat-syarat tertentu, dalam suatu perjanjian, isinya harus ada syaratsyarat tertentu, karena suatu perjanjian yang sah, mengikat sebagai undang-undang bagi mereka yang membuatnya. Agar suatu perjanjian dapat dikatakan sebagai suatu perjanjian yang sah, perjanjian tersebut telah memenuhi syarat-syarat tertentu."9

Oleh karena dalam pasal tersebut tidak disebutkan suatu formalitas tertentu disamping kesepakatan yang telah tercapai itu, maka disimpulkan bahwa setiap perjanjian itu sudahlah sah (dalam arti mengikat) apabila sudah tercapai kesepakatan mengenai hal-hal yang pokok dari perjanjian itu.

Mengenai syarat-syarat sahnya suatu perjanjian, pada "Pasal 1320 KUHPerdata menetapkan empat syarat untuk sahnya suatu perikatan, yaitu :

1. Sepakat mereka yang mengikatkan dirinya

Sepakat mereka yang mengikat dirinya mengandung makna bahwa para pihak yang membuat perjanjian telah sepakat

${ }^{9}$ Mohd.Syaufii Syamsuddin, 2005, Perjanjian-Perjanjian dalam Hubungan Industrial, Sarana Bhakti Persada, Jakarta, hal. 5-6. 
atau ada persesuaian kemauan atau saling menyetujui kehendak masing-masing, yang dilahirkan para pihak dengan tidak ada paksaan kekeliruan dan penipuan. Persetujuan mana dapat dinyatakan secara tegas maupun secara diamdiam.

Ada empat teori yang mencoba memberikan penyelesaian persoalan itu sebagai berikut:

a. Uitings theorie (teori saat melahirkan kemauan)

Menurut teori ini perjanjian terjadi apabia atas penawaran telah dilahirkan kemauan menerimanya dari pihak lain. Kemauan ini dapat dikatakan telah dilahirkan pada waktu pihak lain mulai menulis surat penerimaan.

b. Verzend theorie (Teori saat mengirim surat penerimaan) Menurut teori ini perjanjian terjadi pada saat surat penerimaan dikirimkan kepada si penawar.

c. Ontvang theorie (teori saat menerima surat penerimaan) Menurut teori ini perjanjian terjadi pada saat menerima surat penerimaan sampai dialamat sipenawar.

d. Vernemings theorie (teori saat mengetahui surat penerimaan)

Menurut teori ini, perjanjian baru terjadi, apabila si penawar telah membuka dan membaca surat penerimaan itu. ${ }^{10}$

Menurut prof, Dr. Wirjono Prodjodikoro, SH, ontvangs theorie dan Vernemings theorie dapat dikawinkan sedemikian rupa, yaitu dalam keadaan biasa perjanjian harus dianggap terjadi pada saat surat penerimaan sampai pada alamat penawar (ontvangs theorie), tetapi dalam

${ }^{10}$ Riduan Syahrani, 2006, Seluk Beluk dan Asas-Asas Hukum Perdata, PT. Alumni, Bandung, hal. 206. 
keadaan luar biasa kepada sipenawar diberikan kesempatan untuk membuktikan bahwa itu tidak mungkin dapat mengetahui isi surat peneriman pada saat surat itu sampai di alamatnya, melainkan baru beberapa hari kemudian atau beberapa bulan kemudian, misalnya karena bepergian atau sakit keras."11

2. "Kecakapan untuk membuat suatu perikatan

Cakap merupakan syarat umum untuk dapat melakukan perbuatan hukum secara sah yaitu harus sudah dewasa, sehat akal pikiran dan tidak dilarang oleh suatu peraturan perundang-undangan untuk melakukan sesuatu perbuatan tertentu.

Dilihat dari sudut rasa keadilan memang benar-benar perlu bahwa orang yang membuat perjanjian yang nantinya akan terikat oleh perjanjian yang dibuatya itu, harus benar-benar mempunyai kemampuan untuk menginsyafi segala tanggung jawab yang bakal dipikulnya karena perbuatanya itu. ${ }^{12}$ Sedangkan bila dilihat dari sudut ketertiban umum, karena orang yang membuat perjanjian itu mempertaruhkan kekayaanya, sehingga sudah seharusnya orang tersebut sungguh-sungguh berhak berbuat bebas terhadap harta kekayaanya."13

3. "Suatu hal tertentu.

Suatu hal tertentu dalam perjanjian adalah barang yang menjadi objek suatu perjanjian .menurut pasal 1333 BW barang yang menjadi objek suatu perjanjian ini harus tertentu, setidak-tidaknya harus ditentukan jenisnya, sedangkan

11 Prof, Dr, Wirjono Prodjodikoro, SH, 1973, Asas-Asas Hukum Perjanjian, Sumur Bandung, Jakarta, cet VII, hal. 28, 29.

12 Subekti, 2005, Hukum Perjanjian, Intermasa, Jakarta, Cet VI, hal. 18, 19.

${ }^{13}$ Achmad Ichsan, 1967, Hukum Perdata IA, Pembimbing Masa, Jakarta, hal. 126. 
jumlahnya tidak perlu ditentukan, asalkan saja kemudian dapat ditentukan atau diperhitungkan.

4. Suatu sebab yang halal.

Suatu sebab yang halal merupakan syarat yang keempat untuk sahnya perjanjian. Mengenai syarat ini pasal 1335 BW menyatakan bahwa suatu perjanjian tanpa sebab, atau yang telah dibuat karena suatu sebab yang palsu atau terlarang, tidak mempunyai kekuatan

Ternyata pembetukan undang-undang membayangkan 3 macam perjanjian mungkin terjadi yakni 1. Perjanjian yang tanpa sebab, 2. Perjanjian dengan suatu sebab yang palsu atau terlarang dan 3.perjanjian dengan suatu sebab yang halal.

Yang menjadi persoalan pokok dalam hal ini adalah apakah pengertian perkataan sebab itu sebenarnya. Dari sejumlah interpretasi dan penjelasan para ahli, dapat disimpulkan bahwa pengertian perkataan sebab itu adalah sebagai berikut:

a. Perkataan sebab sebagai salah satu syarat perjanjian adalah sebab dalam pengertian ilmu pengetahuan hukum yang berbeda dengan ilmu pengetahan lainya.

b. Perkataan sebab itu bukan pula motif (desakan jiwa yang mendorong seseorang melakukan perbuatan tertentu) karen motif adalah soal bathin yang tidak diperdulikan oleh hukum.

c. Perkataan sebab secara letterlijk berasal dari oorzaak (bahasa belanda) atau causa (bahasa latin) yang menurut riwayatnya bahwa yang dimaksud dengan perkataan itu dalam perjanjian adalah tujuan yakni apa yang dimaksudkan oleh kedua pihak degan mengadakan perjanjian. Dengan perkataan lain sebab berarti isi perjanjian itu sendiri. 
d. Kemungkinan perjanjian tanpa sebab yang dibayangkan dalam pasal 1335 BW adalah suatu kemungkinan yang tidak akan terjadi, karena perjanjian itu sendiri adalah isi bukan tempat yang harus diisi." 14

"Apabila dua syarat yang pertama tidak dipenuhi (a dan b) maka perjanjian dapat dibatalkan (syarat subjektif). Sedangkan apabila dua syarat yang terakhir tidak dipenuhi (c dan d) maka perjanjian ini batal demi hukum (syarat objektif). Perjanjian yang batal demi hukum adalah perjanjian sejak semula batal dan tidak mungkin menimbulkan akibat hukum bagi kedua belah pihak. Perjanjian yang bertentangan dengan undang-undang, kesusilaan dan ketertiban umum adalah batal demi hukum. Sedangkan perjanjian dapat dibatalkan artinya salah satu pihak mempunyai hak untuk meminta agar perjanjian itu dibatalkan."15

"Perjanjian jual beli adalah suatu perjanjian timbal balik dimana pihak yang satu (penjual) berjanji akan menyerahkan suatu barang dan pihak lain (pembeli) akan membayar harga yang telah dijanjikan (pasal 1457 KUHPer)."

Perjanjian jual beli saja tidak lantas menyebabkan beralihnya hak milik atas barang dari tangan penjual ke tanggan pembeli sebelum dilakukan penyerahan (levering). Pada hakekatnya perjanjian jual beli itu dilakukan dalam dua tahap yaitu tahap kesepakatan kedua belah pihak mengenai barang dan harga yang ditandai dengan kata sepakat (Jual beli) dan yang kedua, tahap penyerahan (levering) benda yang menjadi obyek perjanjian, dengan tujuan untuk mengalihkan hak milik dari benda tersebut.

${ }^{14}$ Riduan Syahrani, Op, Cid, hal. 210.

${ }^{15}$ Simanjuntak, Op, Cid, hal. 334. 
"Hak milik beralih dengan adanya penyerahan (levering). Penyerahan adalah suatu pemindahan barang yang telah dijual ke dalam penguasaan dan kepunyaan si pembeli (pasal 1475)." "Jadi penyerahan dapat diartikan sebagai cara untuk mendapatkan hak milik karena adanya pemindahan hak milik akibat dari perjanjian jual beli. Untuk perjanjian jual beli dengan system indent penyerahan barang dilakukan dengan penyerahan kekuasaan atas barang (kendaraan dianalogikan sebagai barang bergerak) sebagaimana diatur dalam pasal 612 KUHPerdata. Biasanya, penyerahan dilakukan langsung ditempat penjual atau ditempat lain yang telah diperjanjikan sebelumnya"

"Tidak jarang terjadi hubungan perdata diantara para pihak dalam bentuk perjanjian, tetapi tidak didukung oleh bukti-bukti. Dalam persoalan seperti itu, jangankan penyelesaian nonlitigasi secara litigasi pun sangat sulit, sebab setiap dalil yang akan dikemukakan harus dibuktikan. Permasalahan ini sering terjadi dalam perjanjian lisan/Tidak Tertulis, dimana salah satu pihak melakukan wan prestasi karena ia berdalih bahwa tidak pernah ada perjanjian. Kasus seperti itu perlu dikonstruksikan bukti-bukti agar perbuatan hukum itu dapat diselesaikan dengan dasar tuntutan yang jelas. Di dalam rumusan Pasal 1865 KUHPerdata menyebutkan bahwa "barang siapa mendalilkan sesuatu hak harus membuktikannya". Oleh karena itu, jika peristiwa hukum yang terjadi seperti yang disebutkan diatas, maka harus dilakukan konstruksi bukti hukum agar perbuatan hukum tanpa bukti hukum itu mendapat dasar penyelesaiannya. Misalnya, pinjam-meminjam uang dari tangan ke tangan tanpa bukti kuitansi, tanpa ada saksi, sedangkan perbuatan itu oleh para pihak sama-sama diakui dilakukan. Di dalam rumusan Pasal 1866 KUHPerdata disebutkan 
"alat bukti yang dapat dipakai untuk membuktikan suatu dalil terdiri atas : bukti tulisan; bukti saksi; persangkaan; pengakuan; dan sumpah. Pengakuan di luar pengadilan tidak mengikat, maka untuk menguatkan pengakuan itu haruslah dikonstruksikan hukum dengan saksi-saksi, yaitu para pihak pada saat membicarakan cara perbuatan pinjam-meminjam itu, dihadirkan dua orang saksi, untuk membuktikan jika nantinya terjadi sengketa dipengadilan, walupun pinjammeminjam uang itu tidak disertai dengan kuitansi, akan tetapi olah karena saling pengakuan oleh para pihak sudah didengar oleh dua orang saksi (unnus testis nullus testis), maka perbuatan hukum tersebut menjadi terbukti. Konstruksi hukum dengan saksi ini dapat dilakukan terhadap segala perbuatan hukum tanpa bukti, termasuk perjanjian yang dilakukan secara lisan, tetapi dengan ketentuan saksi tersebut tidak memiliki hubungan keluarga dengan para pihak (rumusan Pasal 1910 KUHPerdata) dan saksi cakap bertindak menurut hukum (rumusan Pasal 1330 KUHPerdata).”16

"Sebagai alat bukti tertulis surat dibagi dua (2) yaitu surat yang merupakan akta dan yang bukan akta. Sedagkan akta itu sendiri terbagi lagi dalam akta autentik dan akta dibawah tangan. ${ }^{17}$

\section{Akta Autentik}

Adalah suatu akta yang bentuknya ditentukan oleh undangundang, dibuat oleh atau dihadapan penjabat umum yang berwenang untuk itu tempat dimana akta itu dibuatnya.(pasal 1868 KUHPer).

Keistimewaan akta Autentik adalah merupakan suatu alat bukti yang sempurna (Volleding Bewijs tentang apa yang

16 I Wayan Wiryawan dan I Ketut Artadi, 2010, Penyelesaian Sengketa Di Luar Pengadilan, Udayana University Press, Denpasar-Bali, hal. 40-41.

${ }^{17}$ Soeroso, 2011, Perjanjian Dibawah Tangan Pedoman Praktis Pembuatan dan Aplikasi Hukum, Sinar Grafika, Jakarta, hal. 7. 
dibuat didalamnya), artinya apabila seseorang mengajukan akta Autentik kepada hakim sebagai bukti, maka hakim harus menerima dan menganggap apa yang tertulis didalam akta merupakan peristiwa yang sungguh-sungguh telah terjadi dan hakim tidak boleh memerintahkan penambahan pembuktian.

Dalam hal suatu perjanjian apa yang dijanjikan dinyatakan dalam akta Autentik itu adalah benar seperti apa yang telah diperjanjikan, dinyatakan oleh para pihak sebagai yang dilihat dan didengar oleh notaris terutama benar mengenai tanggal akta, tanda tangan didalam akta, identitas yang hadir, dan tempat dibuat akta itu, merupakan kekuatan pembuktian formal. Sedangkan kekuatan pembuktiaan materil isi atau materi akta adalah benar. ${ }^{18}$

\section{Akta di Bawah Tangan}

Yang dimaksud dengan akta dibawah tangan atau onderhands acte adalah akta yang dibuat tidak oleh atau tanpa perantaraan seseorang penjabat umum, melainkan dibuat dan ditanda tangani sendiri oleh para pihak yang mengadakan perjanjian, misalnya perjanjian jual beli atau perjanjian sewamenyewa.

Dalam hal apabila para pihak yang menandatangani surat perjanjian tersebut mengakui dan tidak menyangkal tanda tanganya, tidak menyangkal isi dan apa yang tertulis dalam surat perjanjian itu, maka akta dibawah tangan tersebut mempunyai kekuatan pembuktian yang sama dengan suatu akta autentik atau resmi."

"pasal 1875 KUHPer menyatakan bahwa : 
suatu tulisan dibawah tangan yang diakui oleh orang terhadap siapa tulisan itu hendak dipakai atau yang dengan cara menurut undang-undang dianggap sebagai diakui memberikan terhadap orang-orang yang menandatanganinya serta para ahli warisnya dan orang-orang yang mendapat hak dari mereka, bukti yang sempurna seperti suatu akta autentik dan demikian pula berlakulah ketentuan pasal 1871 untuk tulisan itu, yang dalam ayat 2 berbunyi :

jika apa yang termuat disitu sebagai suatu penuturan belaka tidak ada hubunganya langsung dengan pokok isi akta, maka itu hanya dapat berguna sebagai permulaan pembuktian dengan tulisan." 19

Kemudian yang menjadi tujuan pembahasan berikutnya yaitu hak-hak dan kewajiban yang dimiliki penjual maupun pembeli dalam proses perjanjian jual beli yaitu Hak dan kewajiban antara pembeli dan penjual yaitu :

Hak dan Kewajiban Penjual

Penjual memiliki dua kewajiban utama yaitu menyerahkan hak milik atas barang dan barang menanggung kenikmatan tenteram atas barang tersebut dan menanggung cacat tersembunyi. Sebaliknya "Pembeli memiliki hak atas pembayaran harga barang, hak untuk menyatakan pembatalan berdasarkan pasal 1518 KUHPerd dan hak reklame."

Hak dan Kewajiban Pembeli

Pembeli berkewajiban membayar harga barang sebagai imbalan haknya untuk menuntut penyerahan hak milik atas barang yang dibelinya. Pembayaran harga dilakukan pada waktu dan tempat yang ditetapkan dalam perjanjian. Harga tersebut harus berupa uang. Meski mengenai hal ini tidak ditetapkan oleh undang-undang namun 
dalam istilah jual-beli sudah termaktub pengertian disatu pihak ada barang dan dilain pihak ada uang,

Sedangkan perlindungan hukum dalam proses perjanjian jual beli adanya persetujuan sudah cukup membuktikan bahwa telah terjadi hubungan keperdataan, dimana suatu perikatan telah timbul yang diakibatkan suatu perbuatan hukum (rechtshandeling) antara satu orang atau lebih sebagaimana diatur dalam "Pasal 1313 dan Pasal 1314 Kitab Undang-Undang Hukum Perdata ("KUHPer"). dapat dipahami bahwa suatu persetujuan sudah dapat membuktikan adanya kewajiban dan hak (akibat hukum) yang ditimbul dari pihak-pihak yang bersepakat. Pada dasarnya, perjanjian tidak harus dibuat secara tertulis, kecuali diharuskan oleh peraturan perundang-undangan.”

Perjanjian yang dibuat secara lisan/tidak tertulis pun tetap mengikat para pihak, dan tidak menghilangkan, baik hak dan kewajiban dari pihak yang bersepakat. Namun, untuk kemudahan pembuktian, acuan bekerja sama dan melaksanakan transaksi, sebaiknya dibuat secara tertulis. Hal ini juga dimaksudkan, agar apabila terdapat perbedaan pendapat dapat kembali mengacu kepada perjanjian yang telah disepakati.

"Perlu dipahami bahwa suatu persetujuan wajib dilakukan dengan iktikad baik bagi mereka yang melakukannya, dan karenanya sifat mengikat dari persetujuan tersebut adalah pasti dan wajib. Sebagaimana diatur dalam Pasal 1338 KUHPer dan Pasal 1339 KUHPer. Berdasarkan ketentuan mengenai syarat sahnya suatu perjanjian tersebut, tidak ada satupun syarat dalam Pasal $1320 \mathrm{KUH}$ Perdata” yang mengharuskan suatu perjanjian dibuat secara tertulis.

Hukum Perdata Mengatur Tentang Perjanjian Jual Beli 
"Dalam KUH Perdata Buku III tentang Perikatan (van verbintenis) tidak mendefenisikan tentang perikatan. Akan tetapi diawali dengan pasal 1233 BW mengenai sumber-sumber perikatan, yaitu Perikatan, lahir karena suatu persetujuan atau karena undangundang." Dengan demikian kontrak atau perjanjian merupakan salah satu dari dua dasar hukum yang ada selain dari undang-undang yang dapat menimbulkan perikatan.

"Menurut C. Asser, ciri utama perikatan adalah hubungan hukum antara para pihak, yang menimbulkan hak (prestasi) dan kewajiban (kontra prestasi) yang saling dipertukarkan oleh para pihak."20

"Menurut Agus Yudha Hernoko, terdapat 4 (empat) unsur perikatan, yaitu :

a. hubungan hukum, artinya perikatan yang dimaksud disini adalah bentuk hubungan hukum yang menimbulkan akibat hukum

b. bersifat harta kekayaan, artinya sesuai dengan tempat pengaturan perikatan di Buku III BW yang termasuk di dalam sistematika Hukum Harta Kekayaan (Vermogensrecht), maka hubungan yang terjalin antar para pihak tersebut berorientasi pada harta kekayaan.

c. para pihak, artinya dalam hubungan hukum tersebut melibatkan pihak-pihak sebagai subyek hukum

d. prestasi, artinya hubungan hukum tersebut melahirkan kewajiban-kewajiban (prestasi) kepada para pihaknya (prestasi - kontra prestasi), yang pada kondisi tertentu dapat dipaksakan pemenuhannya, bahkan apabila diperlukan menggunakan alat Negara."21

${ }^{20}$ Setiawan, .1987, Pokok-pokok Hukum Perikatan, Bina Cipta, Jakarta, hal.49.

${ }^{21}$ C. Asser, 1991, Pengkajian Hukum Perdata Belanda, Dian Rakyat, Jakarta, hlm.5. 
"Suatu perjanjian adalah suatu peristiwa dimana seorang berjanji kepada seorang lain atau dimana dua orang itu saling berjanji untuk melaksanakan sesuatu hal. Dari peristiwa ini, timbullah suatu hubungan antara dua orang tersebut yang dinamakan perikatan. Perjanjian itu menerbitkan suatu perikatan antara dua orang yang membuatnya. Dalam bentuknya, perjanjian itu berupa suatu rangkaian perkataan yang mengandung janji-janji atau kesanggupan yang diucapkan atau ditulis"22

Menurut Pasal 1313 KUHPerdata, "Suatu persetujuan adalah suatu perbuatan dengan mana satu orang atau lebih mengikatkan dirinya terhadap satu orang atau lebih."23

"Sarjana Hukum Perdata pada umumnya berpendapat bahwa definisi perjanjian yang terdapat di dalam ketentuan tersebut tidak lengkap dan terlalu luas. Tidak lengkap karena hanya mengenai perjanjian sepihak saja dan dikatakan terlalu luas karena dapat mencakup hal-hal yang mengenai janji kawin, yaitu perbuatan di dalam lapangan hukum keluarga yang menimbulkan perjanjian juga, tetapi, bersifat istimewa karena diatur dalam ketentuan-ketentuan tersendiri sehingga Buku III KUHPerdata secara langsung tidak berlaku terhadapnya. Juga mencakup perbuatan melawan hukum, sedangkan di dalam perbuatan melawan hukum ini tidak ada unsur persetujuan." 24

Menurut Salim HS, Perjanjian adalah "hubungan hukum antara subjek yang satu dengan subjek yang lain dalam bidang harta kekayaan, dimana subjek hukum yang satu berhak atas prestasi dan

${ }^{22}$ Prof. R. Subekti, S.H., 1987, Hukum Perjanjian, Citra Aditya Bhakti, Jakarta, Cet. Ke4.

${ }^{23}$ Sudarsono, 2007, Kamus Hukum, Rincka Cipta, Jakarta, hal. 363.

${ }^{24}$ Mariam Darus Badrulzaman, 2005, KUHPerdata Buku III Hukum Perikatan dengan Penjelasan, Alumi, Bandung, hal. 89. 
begitu juga subjek hukum yang lain berkewajiban untuk melaksanakan prestasinya sesuai dengan yang telah disepakatinya."25

"Menurut Gunawan Widjaja dan Kartini Muljadi, ketentuan umum mengenai perikatan untuk menyerahkan sesuatu (Pasal 1235KUHPerdata), dan ketentuan yang diatur secara khusus dalam ketentuan jual-beli (Pasal 1474), penjual memiliki 3 (tiga) kewajiban pokok mulai dari sejak jual-beli terjadi menurut ketentuan Pasal 1458KUHPerdata. Menurut ketentuan tersebut, secara prinsip penjual memiliki kewajiban untuk:

a. Memelihara dan merawat kebendaan yang akan diserahkankepada pembeli hingga saat penyerahannya.

b. Menyerahkan kebendaan yang dijual pada saat yang telahditentukan, atau jika tidak telah ditentukan saatnya, ataspermintaan pembeli.

c. Menanggung kebendaan yang dijual tersebut.Dalam Pasal 1474 KUHPerdata menjelaskan bahwa, sebagaipihak penjual memiliki dua kewajiban penting dalam pelaksanaanperjanjian. Kewajiban tersebut adalah menyerahkan suatu barang dan menanggungnya."

Mengenai penyerahan atau levering dalam KUHPerdata,menganut 'sistem causal' yaitu suatu sistem yang menggantungkansahnya levering itu pada dua syarat :

a. Penyerahan atau levering telah dilaksanakan oleh yangberhak berbuat bebas (beschikking sbevoegd) terhadaporang yang dilevering.

b. Sahnya titel dalam perjanjian jual beli yang menjadi dasarlevering (penyerahan).Dari syarat tersebut diatas, khususnya sahnya titel yang menjadidasar levering,

${ }^{25}$ Salim HS, 2008, Hukum Kontrak, Teori \& Tekriik Penyusunan Kontrak, Sinar Grafika, Jakarta, hal. 27. 
dimaksudkan perjanjian obligator yang menjadi dasarleveringtersebut. Adapun orang yang 'berhak berbuat bebas' adalahpemilik barang sendiri atau orang yang dikuasakan olehnya.Mengenai penanggungan terhadap suatu barang dan atau barangyang kondisinya rusak (cacat produk) lebih lanjut diatur dalam Pasal1504 KUHPerdata, yang menyatakan bahwa:

"Si penjual diwajibkan menanggung terhadap cacat-cacat tersembunyi pada barang yang dijual, yang membuatbarang itu tidak sanggup untuk pemakaian yangdinaksudkan, atau yang demikian mengurangi pemakaianitusehingga, seandainya si pembeli mengetahui cacatcacatitu, ia sama sekali tidak akan membeli barangnya,atau tidak akan membelinya selain dengan harga yangkurang."

Hak dan kewajiban Pihak Pembeli.

Kewajiban utama si pembeli ialah membayar harga pembelian pada waktu dan tempat sebagaimana ditetapkan menurut perjanjian.

"Kewajiban utama pihak pembeli menurut Pasal 1513KUHPerdata adalah membayar harga pembelian pada waktu danditempat sebagaimana ditetapkan menurut perjanjian.Jika pada waktumembuat perjanjian tidak ditetapkan tentang itu, si pembeli harusmem bayar ditempat dan pada waktu dimana penyerahan harus dilakukan (Pasal 1514 KUHPerdata). Menurut Pasal 1515KUHPerdata, meskipun pembeli tidak ada suatu janji yang tegas, diwajibkan membayar bunga dari harga pembelian, jika barang yangdijual dan diserahkan memberi hasil atau lain pendapatan.Sedangkan yang menjadi hak pembeli adalah menuntutpenyerahan barang yang telah dibelinya dari si penjual. Penyerahantersebut, oleh penjual kepada pembeli menerut ketentuan 
Pasal 1459KUHPerdata merupakan cara peralihan hak milik dari kebendaan yang dijual tersebut."26

"Sedangkan hak dan kewajiban penjual dan pembeli berdasarkan Undang-Undang Perlindungan Konsumen. ketentuan Pasal 7 Undang-Undang Nomor 8 tahun 1999 tentang Perlindungan Konsumen, diatur mengenai kewajiban-kewajiban pelaku usaha, dalam hal ini penjual yang menawarkan dan menjual suatu produk, yaitu :

1. beritikad baik dalam melakukan kegiatan usahanya

2. memberikan informasi yang benar, jelas dan jujur mengenai kondisi dan jaminan barang dan atau jasa serta memberikan penjelasan penggunaan, perbaikan dan pemeliharaan

3. memperlakukan atau melayani konsumen secara benar, jujur dan tidak diskriminatif

4. menjamin mutu barang dan/atau jasa yang diproduksi dan/atau diperdagangkan berdasarkan ketentuan standar mutu barang dan/atau jasa yang berlaku

5. memberi kesempatan kepada konsumen untuk menguji dan atau mencoba barang dan/atau jasa tertentu serta memberi jaminan dan atau garansi atas barang yang dibuat dan/atau yang diperdagangkan

6. memberi kompensasi, ganti rugi, dan/atau penggantian atas kerugian akibat penggunaan, pemakaian dan pemanfaatan barang dan/atau jasa yang diperdagangkan;memberi kompensasi, ganti rugi dan/atau penggantian apabila barang dan/atau jasa yang diterima tidak sesuai dengan perjanjian."27 “penjual juga memiliki hak dalam proses jual beli antara lain :

${ }^{26}$ Prof. Subekti, $\mathrm{Op}, \mathrm{Ci}$, hal 20

${ }^{27}$ Undang-Undang Nomor 8 tahun 1999 tentang Perlindungan Konsumen 
1. Menentukan dan menerima harga permbayaran atas penjualan barang, yang kemudian harus disepakati oleh pembeli.

2. Penjual juga berhak mendapatkan perlindungan hukum dari tindakan pembeli yang beritikad tidak baik, kemudian haknya untuk melakukan pembelaan diri sepatutnya dalam suatu penyelesaian sengketa yang dikarenakan barang yang dijualnya, dalam hal ini tidak terbukti adanya kesalahan penjual., dan sebagainya.

Sesuai dengan ketentuan Pasal 6, pelaku usaha dalam hal ini termasuk penjual memiliki hak-hak sebagai berikut:

1. Hak untuk menerima pembayaran yang sesuai dengan kesepakatan dengan kesepakatan mengenai kondisi dan nilai tukar barang dan atau jasa yang diperdagangkan

2. Hak untuk mendapat perlindungan hukum dari tindakan konsumen yang beritikad tidak baik

3. Hak untuk melakukan pembelaan diri sepatutnya dalam penyelesaian sengketa

4. Hak untuk rehabilitasi nama baik apabila terbukti secara hukum bahwa kerugian konsumen tidak diakibatkan oleh barang dan atau jasa yang diperdagangkan

5. Hak-hak diatur dalam ketentuan peraturan perundangundangan."

"Selain hak dan kewajiban penjual, ada juga hak dan kewajiban pembeli sebagai pihak dalam perjanjian jual beli. Kewajiban pembeli juga termuat dalam Undang-Undang Nomor 8 tahun 1999 Tentang Perlindungan Konsumen. Pembeli sebagai konsumen mempunyai kewajiban dalam proses jual beli sebagai berikut:

1. Membaca informasi dan mengikuti prosedur atau petunjuk tentang penggunaan barang dan atau jasa yang dibelinya. 
2. Beritikad baik dalam melakukan transaksi jual beli barang dan atau jasa tersebut.

3. Membayar harga pembelian pada waktu dan di tempat sebagaimana ditetapkan menurut perjanjian sesuai nilai tukar yang telah disepakati. Harga termaksud berupa sejumlah uang meskipun hal ini tidak ditegaskan dalam undang-undang, tetapi dianggap telah terkandung dalam pengertian jual beli sebagaimana diatur dalam Pasal 1465 KUH Perdata, apabila pembayaran tersebut berupa barang, maka hal tersebut menggambarkan bahwa yang terjadi bukanlah suatu proses jual beli tapi tukar menukar, atau pembayaran yang dimaksud berupa jasa berarti mencerminkan perjanjian kerja. Pada dasarnya harga dalam suatu perjanjian jual beli ditentukan berdasarkan kesepakatan dua pihak, namun pada kenyataannya ada juga harga dalam jual beli yang ditentukan oleh pihak ketiga, dengan demikian, hal tersebut dianggap sebagai perjanjian jual beli dengan syarat tangguh, yang mana perjanjian dianggap ada pada saat pihak ketiga menentukan harga termaksud. Berdasarkan Pasal 1465 KUH Perdata, segala biaya untuk membuat akta jual beli dan biaya tambahan lainnya ditanggung oleh pembeli, kecual diperjanjikan sebaliknya. Selain harga pembayaran dalam suatu proses jual beli diatur pula mengenai waktu dan tempat dilakukannya pembayaran, biasanya pembayaran dilakukan di tempat dan pada saat diserahkannya barang yang diperjual belikan atau pada saat levering, sebagaimana diatur dalam Pasal $1514 \mathrm{KUH}$ Perdata yang menyebutkan bahwa apabila pada saat perjanjian jual beli dibuat tidak ditentukan waktu dan tempat pembayaran maka pembayaran ini harus dilakukan ditempat dan pada waktu penyerahan barang. 
4. Biaya akta-akta jual beli serta biaya lainnya ditanggung oleh pembeli.

5. Mengikuti upaya penyelesaian hukum secara patut apabila timbul sengketa dari proses jual beli termaksud." 28

"Selain kewajiban yang harus dilakukannya, pembeli yang dianggap sebagai konsumen juga memiliki hak dalam proses jual beli sebagaimana diatur dalam Pasal 4 Undang-Undang Perlindungan Konsumen, antara lain :

1. Hak atas kenyamanan, keamanan dan keselamatan dalam mengkonsumsi barang dan atau jasa.

2. Hak untuk memilih serta mendapatkan barang dan atau jasa dengan kondisi yang sesuai dengan yang diperjanjikan.

3. Hak untuk mendapatkan informasi secara benar, jujur, dan jelas mengenai barang dan atau jasa yang diperjualbelikan

4. Hak untuk mendapatkan pelayanan dan perlakuan secara benar dan tidak diskriminatif

5. Hak untuk didengarkan pendapatnya atau keluhannya atas kondisi barang dan atau jasa yang dibelinya.

6. Hak untuk mendapatkan perlindungan hukum secara patut apabila dari proses jual beli tersebut timbul sengketa.

7. Hak untuk mendapatkan kompensasi atau ganti rugi apabila barang dan atau jasa yang dibelinya tidak sesuai dengan apa yang diperjanjikan." 29

\section{PENUTUP}

\section{Kesimpulan}

Mengenai pembahasan diatas dapat disimpulkan.

${ }^{28}$ Burgerlijk Wetboek

${ }^{29}$ Undang-Undang Nomor 8 tahun 1999 tentang Perlindungan Konsumen, 
1. Keabsahan Perjanjian Jual Beli Secara Tidak Tertulis, Perjanjian jual-beli merupakan jenis perjanjian timbal balik yang melibatkan dua pihak yaitu penjual dan pembeli. Kedua belah pihak yang membuat perjanjian jual-beli masing-masing memiliki hak dan kewajiban untuk melaksanakan isi perjanjian yang mereka buat. Perjanjian Lisan/Tidak Tertulis yaitu perjanjian yang kesepakatan/klausul yang diperjanjikan disepakati secara lisan/Tidak Tertulis. "Perjanjian lisan/Tidak Tertulis seperti ini tetaplah sah, tetapi yang menjadi masalah adalah jika ada sengketa yang lahir terkait dengan perjanjian ini maka para pihak akan kesulitan melakukan pembuktian. Perlindungan hukum dalam proses perjanjian jual beli adanya persetujuan sudah cukup membuktikan bahwa telah terjadi hubungan keperdataan, dimana suatu perikatan telah timbul yang diakibatkan suatu perbuatan hukum (rechtshandeling) antara satu orang atau lebih sebagaimana diatur dalam Pasal 1313 dan Pasal 1314 Kitab Undang-Undang Hukum Perdata" ("KUHPer"). dapat dipahami bahwa suatu persetujuan sudah dapat membuktikan adanya kewajiban dan hak (akibat hukum) yang ditimbul dari pihak-pihak yang bersepakat. Pada dasarnya, perjanjian tidak harus dibuat secara tertulis, kecuali diharuskan oleh peraturan perundang-undangan.

2. Hukum Perdata Mengatur Tentang Perjanjian Jual Beli, Jual beli merupakan bentuk transaksi umum yang sering dilakukan oleh masyarakat. Biasanya, perjanjian jual beli dilakukan secara lisan atau tertulis atas dasar kesepakatan para pihak (penjual dan pembeli), "Dalam KUH Perdata Buku III tentang Perikatan (van verbintenis)" tidak mendefenisikan tentang perikatan. "Akan tetapi diawali dengan pasal 1233 BW mengenai sumber-sumber perikatan, yaitu Perikatan, lahir karena suatu persetujuan atau karena undang-undang." Dengan demikian kontrak atau perjanjian 
merupakan salah satu dari dua dasar hukum yang ada selain dari undang-undang yang dapat menimbulkan perikatan.

\section{Saran}

Ada beberapa saran yang dapat penulis berikan.

1. Keabsahan Perjanjian Jual Beli Secara Tidak Tertulis, untuk mencegah kerugian antara kedua belah pihak yang melakukan suatu perjanjian Jual beli, sebaiknya perjanjian dimuat secara tertulis maksud dari hal ini, jika terdapat pihak yang melanggar dalam proses perjanjian, hal ini bisa melihat kembali pada isi perjanjian dan pembuktianya cukup sempurna ditambah dengan adanya saksi dalam suatu perjanjian. "Dalam proses pembuktian suatu perkara perdata, lazimnya alat bukti yang dipergunakan oleh pihak yang mendalilkan sesuatu (Vide Pasal 163 HIR) adalah alat bukti surat." Hal ini karena dalam suatu hubungan keperdataan, suatu surat/akta memang sengaja dibuat dengan maksud untuk memudahkan proses pembuktian, apabila di kemudian hari terdapat sengketa perdata antara pihak-pihak yang terkait.

2. Hukum Perdata Mengatur Tentang Perjanjian Jual Beli, Pembeli dan penjual antar kedua belah pihak harus menyimak betul tentang keabsahan suatu perjanjian sebagaimana tertera dalam pasal 1320 bahwa suatu perjanjian apabila sah, sepakat mereka yang mengikat dirinya, Kecakapan untuk membuat suatu perjanjian, Suatu hal tertentu, Suatu sebab yang halal.

\section{DAFTAR PUSTAKA}

\section{Buku-Buku :}

Agus Yudha Hernoko, 2010, Hukum Perjanjian Asas Proporsionalitas dalam Kontrak Komersil, Jakarta: PT. Kharisma Putra Utama. 
Salim HS, 2008, Hukum Kontrak, Teori \& Tekriik Penyusunan Kontrak, Jakarta: Sinar Grafika.

Subekti, 1995, Aneka perjanjian, Bandung: PT. Citra Aditya Bakti.

2005, Hukum Perjanjian, Jakarta: Intermasa 1987, Hukum Perjanjian, Jakarta: Citra Aditya Bhakti

Simanjuntak, 2007, Pokok-Pokok Hukum Perdata Indonesia, Jakarta: Djambatan.

Amiruddin Dan Zainal Asikin, 2004, Pengantar Metode Penelitian Hukum, Jakarta: PT Raja Grafindo Persada,

Mohd. Syaufii Syamsuddin, 2005, Perjanjian-Perjanjian dalam Hubungan Industrial, Jakarta: Sarana Bhakti Persada.

Riduan Syahrani, 2006, Seluk Beluk dan Asas-Asas Hukum Perdata, Bandung: PT. Alumni.

Prof, Dr, Wirjono Prodjodikoro, SH, 1973, Asas-Asas Hukum Perjanjian, Jakarta: Sumur Bandung, cet VII.

Achmad Ichsan, 1967, Hukum Perdata IA, Jakarta: Pembimbing Masa. I Wayan Wiryawan dan I Ketut Artadi, 2010, Penyelesaian Sengketa Di Luar Pengadilan, Denpasar-Bali: Udayana University Press.

Soeroso, 2011, Perjanjian Dibawah Tangan Pedoman Praktis Pembuatan dan Aplikasi Hukum, Jakarta: Sinar Grafika.

Setiawan, .1987, Pokok-pokok Hukum Perikatan, Jakarta: Bina Cipta.

C. Asser, 1991, Pengkajian Hukum Perdata Belanda, Jakarta: Dian Rakyat.

Sudarsono, 2007, Kamus Hukum, Jakarta: Rincka Cipta.

Mariam Darus Badrulzaman, 2005, KUHPerdata Buku III Hukum Perikatan dengan Penjelasan, Bandung: Alumi.

Aturan Perundang-Undangan

KUHPer

Undang-Undang Nomor 8 tahun 1999 tentang Perlindungan

Konsumen, 